\title{
IAMJ
}

INTERNATIONAL

AYURVEDIC

MEDICAL JOURNAL

\section{EFFECT OF PANCHAKARMA AND AYURVEDIC TREATMENT IN POSTPARTUM RHEUMATOID ARTHRITIS (AMAVATA): A CASE STUDY}

\section{Tushar Suresh Punse}

Assistant Professor, Dept. Kayachikitsa, Shri Gurudev Ayurved College, Ganesh Vihar, Gurukunj Ashram Mozari, Tal. Tiosa Dist. Amravati Maharashtra - 444902, India

Corresponding Author: tusharpunse4@gmail.com

\section{https://doi.org/10.46607/iamj3808122020}

(Published online: December 2020)

Open Access

(C) International Ayurvedic Medical Journal, India 2020

Article Received: 12/11/2020 - Peer Reviewed: 14/11/2020 - Accepted for Publication: 19/11/2020

\section{Check for updates}

\section{ABSTRACT}

Dream of a mother is to get involved actively in upbringing of child, which is impeded if she is suffering from painful condition like rheumatoid arthritis (RA) in postpartum phase. It causes physical incapacity and psychological trauma as well. Present case is a patient who developed RA one month after full term delivery by caesarean section. In view of symptoms, she was diagnosed as case of Amavata. She received Ayurvedic treatment Simhanada Guggulu, Pratapalankeshwara Rasa, Dashamoola katutraya kashaya and combination of Swarnabhupati rasa, Tapyadi loha, Mahavatavidhvansa, Chopachini (Smilax china), Shunthi (Zinziber officinale) and Guduchi (Tinospora Cordifolia) for four months and course of Kala basti (medicated enema) along with application of medicated oil (Vishagharbha Taila Abhyanga) and sudation (Bashpa sweda) for ten days. Complete remission was seen after treatment for four months. The patient was free from oral analgesics. RA test titer that was 160 international units per milliliter $(\mathrm{IU} / \mathrm{ml})$ before treatment showed marked reduction $(28.12 \mathrm{IU} / \mathrm{ml})$ after 75 days of treatment and later dropped in normal range $(6.1 \mathrm{IU} / \mathrm{ml})$. Normal milestones were seen in the child receiving breast feeding. Application of Ayurvedic principles showed excellent results in this case where modern medical management options were limited due to lactation.

Keywords: Arthritis, Lactation, Basti, Swarnabhupati Rasa, RA factor 


\section{INTRODUCTION}

Rheumatoid arthritis (RA) is a chronic multi-system disease, with characteristic features of persistent inflammatory synovitis that usually involve peripheral joints in symmetric distribution. Persistent synovial inflammation often causes cartilage damage and bone erosions that badly disturbs joint integrity, as an outcome of which one third of patients suffer from working disability by five years. RA is correlated with amavata mentioned in Ayurveda Further discussed patient is a known case of RA showing classical symptoms, with positive RA factor and raised erythrocyte sedimentation ratio (ESR). Patient had history of delivery by caesarean section seven months before. In view of lactating phase and inability to cope up with baby care, it was necessary to provide quick relief by using safe treatment modalities not just for the mother but for the child as well. The patient was diagnosed as a case of Amavata and was treated according to principles of treatment of Amavata. She received oral Ayurvedic medicines for four months and a course panchakarma treatment of application of medicated oil, sudation and Kala Basti (medicated enema) for ten days. Remarkable improvement was noticed in pain, swelling, morning stiffness and restricted joint movement within first two months. Previously, patient used to take oral analgesics, which were sparingly required in only first month. RA factor showed marked reduction after two months which later reduced within normal range. Liver and renal profile after two weeks after completion of treatment were within normal limits.

\section{Case Report}

A 27-year-old female patient came to OPD Department, of Kayachikitsa Shri Gurudev Ayurved College Mozari with complaints of pain and swelling in bilateral corpo-phalangeal joints, both knees and ankles along with morning stiffness lasting $75 \mathrm{e} 90 \mathrm{~min}$, anorexia, body ache for six months. She had history of full-term delivery by caesarean section seven months prior and the said symptoms were seen within a month after delivery. Reasons for caesarean section were prolonged labor and fetal distress. It was first maternity for the patient. Pain was severe and the patient used to take oral analgesics twice daily, but temporary relief was noticed. Physical examination showed tenderness and raised local temperature at affected joints along with stiffness. Radial pulse showed tachycardia (100 beats per minute). Labora- tory investigation showed that RA factor and anti-cyclic citrullinated peptide antibody (anti-CCP antibody) were positive (RA test titer $160 \mathrm{IU} / \mathrm{ml}$ and anti CCP antibody more than 200 units per milliliter). ESR was also raised ( $38 \mathrm{~mm}$ after $1 \mathrm{~h}$ by Wintrob's method). Hemogram showed mild anemia but other parameters were within normal range (hemoglobin $10.8 \mathrm{gm} \%$, total leucocytes 8800 per cubic millimeter). C-reactive protein and uric acid were also within normal range (0.9 milligram per deciliter $(\mathrm{mg} / \mathrm{dl})$ and $3.4 \mathrm{mg} / \mathrm{dl}$ respectively).

\section{Diagnosis}

According to American College of Rheumatology (ACR) and European league against rheumatism (EULAR) criteria 2010, it was case of RA. According to Ayurveda differential diagnoses considered were Amavata, Vatarakta ( gout) and Sandhigatavata ( oste- oarthritis). In view of involvement of small as well as big joints and absence of any symptoms related to vitiation of Rakta ( blood) possibility of Vatarakta was ruled out. The absence of Vatapurna Druti sparsha lead us to rule out Sandhigatavata. Hence owing to the body ache (Angamarda), anorexia (Aruchi), stiffness (Stambha) and severe tenderness at joints it was diagnosed as case of Amavata.

\section{Treatment}

Patient received Simhanada Guggulu $250 \mathrm{mg}$ and Pratapa-Lankeshwara rasa $250 \mathrm{mg}$ thrice daily after food. Dashamoola Katutraya Kashaya was advised 20 $\mathrm{ml}$ twice daily after food with warm water. Combination of Swarnabhupati Rasa $60 \mathrm{mg}$, mahavaTavidhvansa and Tapyadi loha $125 \mathrm{mg}$ each along with Chopachini (Smilax china), Shunthi (Zinziber Officinale) and Guduchi (Tinospora Cordifolia) each $250 \mathrm{mg}$ was advised twice daily with honey. Patient also underwent Panchakarma treatment that included application of medicated oil (Vishagharbha Taila 
Abhyanga) and sudation (Bashpa Sweda) of whole body in wooden steam chamber and Kala Basti (ten sitting of Anuvasana Basti and six sitting of Niruha basti). Anuvasana Basti was administered with Pippalyadi Taila $60 \mathrm{ml}$, honey $10 \mathrm{ml}$ and rock salt (Saidhava) 3 g. For Niruha Basti $500 \mathrm{ml}$ of decoction of Dashamoola, Shunthi (Z. officinale), Guduchi (T. cordi- folia), Punarnava (Boerhavia Diffusa) and Daruharidra (Berberis Aristata) with paste of tamarind and jaggery $100 \mathrm{ml}$, cow's urine (Gomutra) $100 \mathrm{ml}$, Pippalyadi Taila $40 \mathrm{ml}$, honey $30 \mathrm{ml}$ and rock salt (Saidhava) $5 \mathrm{~g}$ was used. Only Anuvasana Basti was administered on first, eighth, ninth and tenth day while both Niruha and Anuvasana were administered from second to seventh day. So, 16 sittings of Kala basti were completed in ten days. Patient continued oral medications and application of Vishagarbha Taila on affected joints at home for further three months.

\section{Treatment outcomes [Table 1]}

At the end of first 15 days of oral medication and Panchakarma treatment, edema and tenderness in both knee and copro - phalangeal joints were slightly reduced but there was marked reduction in bodyache and anorexia. Requirement of analgesics was also slightly reduced (once per day). Morning stiffness was as before. After one month of Panchakarma and 45 days of oral medication there was marked reduction in morning stiffness $(25 \mathrm{e} 30 \mathrm{~min})$. After 75 days of oral medication, tenderness and edema in all affected joints and morning stiffness were grossly reduced. Anorexia and body ache were not seen. Analgesics were required only twice during the period by the patient. Titer of RA factor also dropped to $28.12 \mathrm{IU} / \mathrm{ml}$, slightly above normal range. Patient continued same treatment for two more months. After completing four months of oral medication and Panchakarma, patient was absolutely symptom free and needed no analgesics. She could bear all her responsibility in upbringing of child and could enjoy her motherhood. RA factor was within normal range $(6.1 \mathrm{IU} / \mathrm{ml})$. Hepatic and renal profiles done two weeks after treatment were within normal limits (total serum bilirubin $0.9 \mathrm{mg} / \mathrm{dl}$, indirect $0.3 \mathrm{mg} / \mathrm{dl}$, direct 0.6 $\mathrm{mg} / \mathrm{dl}$, alanine aminotransferase (SGPT) $33 \mathrm{mg} / \mathrm{dl}$, aspartate transaminase (SGOT) $39 \mathrm{mg} / \mathrm{dl}$, serum creatinine $0.8 \mathrm{mg} / \mathrm{dl}$, serum urea $29 \mathrm{mg} / \mathrm{dl}$ ). Patient is continuing regular follow up in our out-patient department and does not show aggravation of the disease

Table 1: Treatment Outcome

\begin{tabular}{|c|c|c|c|c|c|c|c|}
\hline No. & Timeline & Joint pain & $\begin{array}{l}\text { Morning } \\
\text { stiffness }\end{array}$ & Anorexia & Body ache & RA factor & $\begin{array}{l}\text { Analgesics } \\
\text { needed }\end{array}$ \\
\hline 1 & Base line e May 2019 & Severe & $90 \mathrm{~min}$ & Present & Present & $160 \mathrm{IU} / \mathrm{ml}$ & Twice daily \\
\hline 2 & $\begin{array}{l}15 \text { days after treatment e } \\
\text { May } 2019\end{array}$ & $\begin{array}{l}\text { Slightly } \\
\text { reduced }\end{array}$ & $90 \mathrm{~min}$ & $\begin{array}{l}\text { Markedly } \\
\text { reduced }\end{array}$ & $\begin{array}{l}\text { Markedly } \\
\text { reduced }\end{array}$ & Not done & Once daily \\
\hline 3 & $\begin{array}{l}45 \text { days after treatment e } \\
\text { June } 2019\end{array}$ & $\begin{array}{l}\text { Markedly } \\
\text { reduced }\end{array}$ & $25 \mathrm{e} 30 \mathrm{~min}$ & Absent & Absent & Not done & Once daily \\
\hline 4 & $\begin{array}{l}75 \text { days after treatment e } \\
\text { July } 2019\end{array}$ & $\begin{array}{l}\text { Markedly } \\
\text { reduced }\end{array}$ & $15 \mathrm{e} 20 \mathrm{~min}$ & Absent & Absent & $\begin{array}{l}28.12 \\
\mathrm{IU} / \mathrm{ml}\end{array}$ & $\begin{array}{l}\text { Twice in } 30 \\
\text { days }\end{array}$ \\
\hline 5 & $\begin{array}{l}120 \text { days after treatment } \\
\text { e September } 2019\end{array}$ & Absent & Absent & Absent & Absent & $6.1 \mathrm{IU} / \mathrm{ml}$ & Not needed \\
\hline 6 & $\begin{array}{l}\text { One year after treatment } \\
\text { e May } 2020\end{array}$ & Absent & Absent & Absent & Absent & Not done & Not needed \\
\hline
\end{tabular}

Abbreviations: RA e Rheumatoid arthritis, IU/ml e international units per millilitre.

\section{DISCUSSION}

Worldwide prevalence of RA is estimated between $0.3 \%$ and $1 \%$ and is commonly seen in women in developed countries. In India the prevalence is estimated to be $0.75 \%$. Though causes of RA are not yet clearly understood, it is believed to affect persons 
who are genetically susceptible as a manifestation of response to an infectious agent. But it is a well observed fact that there is increased risk of RA in postpartum period. Disability caused due to the disease creates great psychological suffering especially in postpartum stage and may affect baby care as well. In present case along with painful and swollen joints, psychological and social trauma, caused due to inability of patient to look after baby, at the time when needed the most, was matter of concern. Researchers in Ayurveda have correlated RA with Amavata or Vatarakta as well. In present case, in view of typical intense pain, anorexia, body ache and stiffness, lead to the diagnosis of Amavata. Neither aetiological factors of Amavata mention pregnancy or labor as causes nor Amavata is mentioned as puerperal disease in Ayurvedic classics. But pregnancy exerts maternal body to an extent that it leads to severe depletion (Kshaya) of body tissues (Dhatu) along with laxity (Dhatu Shaithilya). It is further aggravated by loss of Rakta ( blood) and Kleda ( fluid) during exhausting process of labor, making maternal body 'Shunyavat' (annihilated). The diseases caused in postpartum phase are difficult to treat. Hence it can be understood that aggravation of vata, seen in puerperal stage is capable of causing amavata. Such causality can only be confirmed by more studies

Ayurveda explain specific diet and strolling pattern in postpartum phase (Sutika Paricharya) which the present patient did not follow. This specific regimen in puerperal stage can help in avoiding diseases at this stage, but it remains unexplored. Aim of treatment in this case, was not only to treat Amavata but also to correct depletion of dhatu seen in postpartum stage and additional concern was lactation. Simhanada Guggulu is the drug of choice in Amavata (RA) due to its capacity to improve digestive fire (Agni), pacify vitiated Vata and Kapha especially in joints and improve strength of joints. Pratapalankeshwara Rasa is beneficial in view of its pacifying effect on Vata aggravated in post- partum stage. Dashamoola Katutraya Kashaya is a unique combination of Dashamoola, Trikatu and Vasa (Adathoda vasica). While all medicines are beneficial in postpartum stage; like Dashamoola are useful in pacifying Vata, Trikatu are helpful in improving digestion, Vasa is useful in nourishing (Prasadana) Rakta ( blood), the combination has added advantage due to its ability to reduce pain in joints. Swarnabhupati Rasa contains Bhasma of gold, copper, iron, silver, mercury, sulfur and Vatsanabha (Aconitum ferox) triturated with juice of Hansapadi (Adiantum philippense). It is a wellknown medicine in different diseases caused due to Vata and Kapha especially related with musculoskeletal system. It also improves digestive fire (Agni). Tapyadi Loha another classical medicine that is beneficial to improve Rakta ( blood). Chopachini Shunthi and Guduchi are useful in digestion of Ama and reduce obstruction in passage of vata. Hence combination of Swarnabhu-Pati Rasa, Tapyadi Loha, Mahavatavidhvansa, Chopachini, Shunthi and Guduchi was useful to remove obstruction in passage of Vata without vitiating it, in digestion of Ama and to relieve pain. Oral medicines received by patient though contained metallic and mineral preparations, no untoward effects were seen on hepatic and renal profiles. Ayurvedic classics confine use of oils for external application and advocate use of dry sudation (Ruksha sweda) in Amavata. It would greatly help in patients having more vitiation of Ama as compared to Vata, so that glutinous (Styana) and slimy (Pichcchila) Ama can be controlled. In present case, in view of severe vitiation of Vata in postpartum stage instead of dry sudation, fomentation with steam (Bashpa Sweda) was seen more effective. Basti is the treatment of choice for Vata ailments. In Amavata, Vaitarana Basti is popular treatment widely practised and studied as well. In this patient considering severe aggravation of Vata in postpartum stage instead of Vaitarana Basti, Kala Basti using medi- cines useful in pacifying Vata and Kapha, reducing edema and pain were used. Multiple medicines along with Panchakarma were necessary in this patient to give wholesome relief. Conventional modern treatment of RA shows promising results but is associated with possible side effects. Also, all medicines are not safe in lactation. Hence medicines available are limited and might be harmless only for short duration. In this case patient was habitual to take oral analgesics. But the 
dependency ended after treatment. Throughout treatment patient continued breast feeding. The baby showed normal growth and development. Having said this, it is important to establish safety of Ayurvedic treatment in lactation through more studies.

\section{CONCLUSION}

Now-a-days, incidence of Amavata in postpartum stage is increasing. With apt application of Ayurveda principles good results can be seen. This is effect seen in this case and needs more studies to substantiate effect of Ayurveda treatment in Amavata (RA).

\section{REFERENCES}

1. Lipsky Peter E. Rheumatoid arthritis. In: Longo DL, Kasper DL, Jameson JL, Fauci AS, Hauser SL, Loscalzo $\mathrm{J}$, editors. Harrison principles of internal medi- cine. 18th ed., vol. II. New York: Mc Graw Hill; 2012. p. $2738 \mathrm{e} 52$.

2. Young A, Dixey J, Kulinskaya E, Cox N, Davies P, Devlin J, et al. Which patients stop working because of rheumatoid arthritis? Results of five years' follow up in 732 patients from the Early RA Study (ERAS). Ann Rheum Dis 2002; 61:335e40.

3. Mahato RR, Dave AL, Shukla VD. A comparative study of Rasona Rasnadi Ghanavati and Simhanada Guggulu on Amavata with special reference to rheumatoid arthritis. Ayu 2011;32(1):46e54.

4. Aletaha D, Neogi T, Silman AJ, Funovits J, Felson DT, Bingham III CO, et al. 2010 rheumatoid arthritis classification criteria e an American College of Rheumatology/European League Against Rheumatism Collaborative Initiative. Arthritis Rheum 2010;62(9):2569e81.

5. Shastri BS, editor. Yogaratnakara of unknown author, Amavata Nidana. 6th ed., vol. I. Varanasi: Chaukhamba Sanskrit Sansthan; 1997. p. 565.

6. Acharya YT, editor. Charaka Samhita of Agnivesha, Chikitsa Sthana; Vata- shonita Chikitsa: chapter 29, Verse 19 e 23. Varanasi: Chaukhamba Surbharati Prakashan; 2011. p. 628. reprint 2011.

7. Acharya YT, editor. Charaka Samhita of Agnivesha, Chikitsa Sthana; Vayta- vyadhi Chikitsa: chapter 28, Verse 37. Varanasi: Chaukhamba Surbharati Prakashan; 2011. p. 618. reprint 2011.
8. Malaviya AN, Kapoor SK, Singh RR, Kumar A, Pande I. Prevalence of rheu- matoid arthritis in the adult Indian population. Rheumatol Int 1993;13(4):131e4.

9. Silman A, Kay A, Brennan P. Timing of pregnancy in relation to the onset of rheumatoid arthritis. Arthritis Rheum 1992;35(2):152e5.

10. Brennan P, Silman A. Breast-feeding and the onset of rheumatoid arthritis. Arthritis Rheum 1994; 37: 808e13.

11. Acharya YT, editor. Charaka Samhita of Agnivesha, Sharira Sthana; Jatisutriya Sharira: chapter 8, Verse 49. Varanasi: Chaukhamba Surbharati Prakashan; 2011. p. 349. reprint 2011.

12. Acharya YT, Acharya NR, editors. Sushruta Samhita of Sushruta, Sharira Sthana; Garbhinivyakarana Sharira: chapter 10, Verse 16 e 20. 6th ed. Vara- nasi: Chaukhamba Orientalia; 1997. p. 389.

13. Shastri BS, editor. Yogaratnakara of unknown author, Amavata Chikitsa. $6^{\text {th }}$ ed., vol. I. Varanasi: Chaukhamba Sanskrit Sansthan; 1997. p. 566e73.

14. Shastri BS, editor. Yogaratnakara of unknown author, Sutikaroga Nidana. 6th ed., vol. II. Varanasi: Chaukhamba Sanskrit Sansthan; 1997. p. 431.

15. Arya SM, editor. Sahasrayogam of unknown author. New Delhi: Central Council for Research in Ayurved and Siddha; 1990. p. 36.

16. Shastri BS, editor. Yogaratnakara of unknown author, Rajayakshma Chikitsa. 6th ed., vol. I. Varanasi: Chaukhamba Sanskrit Sansthan; 1997. p. 388.

17. Sammaritano LR, Bermas BL. Rheumatoid arthritis medications and lactation. Curr Opin Rheumatol 2014;26(3):354e60.

\section{Source of Support: Nil \\ Conflict of Interest: None Declared}

How to cite this URL: Tushar Suresh Punse: Effect Of Panchakarma And Ayurvedic Treatment In Postpartum Rheumatoid Arthritis (Amavata): A Case Study. International Ayurvedic Medical Journal \{online\} 2020 \{cited December, 2020\} Available from: http://www.iamj.in/posts/images/upload/5416 5420.pdf 